\title{
First collection of landrace vegetable crops cultivated in Valle Fértil, Argentina
}

\author{
Asprelli, P.D.; I.M. Lorello, P.N. Occhiuto, L.S. Togno, M.A. Makuch, S.C. García Lampasona and I.E. Peralta
}

\begin{abstract}
SUMMARY
The richness of the cultural values found in the Argentinean Andean communities is integrated by a varied diversity of genetic resources, the development of a sustainable agriculture, and the conservation of the producer's own seeds. Local agriculture is a family economic activity, in which traditional varieties of vegetable landraces are highly appreciated for their flavour, colour and aromas. However; social, economic and environmental factors have an effect on crop diversity conservation. The main aim of this work was to retrieve and maintain a representative collection of traditional crop genetic resources still cultivated in the District of Valle Fértil, San Juan Province, Argentina, and to document the farmers' crop experiences and uses. Fifty families were interviewed; 26 of these donated a total of 49 samples belonging to eight species. The landraces collected showed a geometric distribution, typical of communities with low number of species; and a pattern of dominance. A few species are present in almost all farms while rare species are found in specific environments. Local germplasm recovery can prevent genetic erosion, so that both the formal breeding sector and the farmers can make use of the diversity of this collection.
\end{abstract}

Key words: vegetable landraces; agricultural biodiversity; genetic erosion; germplasm conservation.

Asprelli, P.D.; I.M. Lorello, P.N. Occhiuto, L.S. Togno, M.A. Makuch, S.C. García Lampasona e I.E. Peralta, 2012. Primera colección de hortalizas criollas cultivadas en Valle Fértil, Argentina. Agriscientia XXIX: 41-50

\section{RESUMEN}

La riqueza cultural de las comunidades andinas de la Argentina está integrada por la diversidad de sus recursos genéticos, el desarrollo de un sistema agrícola sostenible y por el mantenimiento de sus semillas. La agricultura local es una actividad económica familiar, donde las variedades tradicionales de hortalizas son muy apreciadas por su sabor, color y aroma. Sin embargo, distintos factores sociales, económicos y ambientales afectan la diversidad de tales cultivos. Los objetivos de este trabajo fueron recuperar y conservar una muestra representativa de los recursos genéticos vegetales tradicionales aún presentes en el departamento de Valle Fértil, provincia de San Juan, Argentina, y documentar las experiencias y usos de ellos por parte de los productores. 
Se entrevistaron 50 familias de las cuales 26 donaron un total de 49 muestras pertenecientes a ocho especies. Las variedades criollas recolectadas mostraron una distribución geométrica típica en comunidades con pocas especies, y un patrón de dominancia donde algunas especies están presentes en casi todas las huertas mientras que especies poco representadas se encuentran en ambientes específicos. La recuperación del germoplasma local puede prevenir la erosión genética, de modo que tanto los mejoradores como los productores puedan aprovechar la diversidad de esta colección.

Palabras clave: hortalizas criollas; biodiversidad agrícola; erosión genética; conservación de germoplasma.

P.D. Asprelli, I.M. Lorello, P.N. Occhiuto, L.S. Togno, M.A. Makuch, S.C. García Lampasona, I.E. Peralta. Facultad de Ciencias Agrarias. Universidad Nacional de Cuyo. Instituto Nacional de Tecnología Agropecuaria. EEA INTA La Consulta. Mendoza, Argentina. Correspondencia a: pasprelli@fca.uncu.edu.ar

\section{INTRODUCTION}

The District of Valle Fértil is located at the eastern boundary of San Juan Province, Argentina (Figure 1). The mountains at Valle Fértil, Huerta, Guayaguas and Catanal are in the western boundary (from north to south) of the district, where small agricultural communities are distributed along the valley. Soils are typically rocky in the western areas, sandy in the northern areas and loamy in the eastern and central regions of the area (Lizana et al., 2002). The climate is typically dry Mediterranean with warm summers and cold winters. The average annual rainfall is $363 \mathrm{~mm}$, but with a high variation from year to year (152-656 mm) mainly from November to March (Lizana et al., 2002) (Figure 2). The local wild fauna and vegetation are those typical of semi-arid valleys, and the rivers are governed by temporary regimes (Lizana et al., 2002). Riverbanks and oasis in the central region of the district and man-made water-retention systems have created diverse soil conditions and microenvironments (Figure 1).

Valle Fértil is substantially rich in mineral resources having 14 mines located along the mountains, where mica, fluorite, beryl, copper, iron, lead and zinc are quarried (Lizana et al., 2002). However, the industrial and wholesale sectors are practically absent. The main tourist attraction is the Ischigualasto National Park located in the north of the district, and declared World Heritage by UNESCO in November 2000. The geological structure dates from 180-230 million years ago, and it is one of the most important geological and paleontological deposits in the world where an arranged and complete sequence of continental sediments from the Triassic period can be seen. The geological evolution and the biologic and climatic history of the Is- chigualasto basin are documented by the richness of vertebrates and plants fossils (Ente Autárquico Ischigualasto, 2008).

The richness of cultural values found in the communities of the area near Los Andes is revealed by the diversity of their genetic resources and their crop cultivation systems (INIAP, 1984; Popenoe et al., 1990; Clausen et al., 1995). These traditional communities developed a sustainable agriculture using their ancestral land practices that are not so aggressive to the environment, and typically keep their own seed that are adapted to local conditions (Ceccarelli et al., 1992).

A landrace is typically a population with a subtle balance in its structure, including genetic polymorphisms for many characters of interest, which can be seen as the result of a symbiotic relationship between crops and humans, as well as from interactions between biological and cultural evolution (Frankel, 1993). Thus, distinctive races emerge and adapt to the many variants and interactions of their natural and cultural environment, where crops are gradually exposed and selected. However, social, economic and environmental factors have an effect on crop diversity and conservation, producing genetic erosion and even the extinction of genetic resources (Brown, 2000). In this context, vegetable crop germplasm recuperation and conservation is a priority because it constitutes valuable genetic sources for plant improvement (Harlan, 1992).

In Valle Fértil, local agriculture is the basis of the family economic activity, which is carried out from early spring (September-October) to autumn (AprilMay). Autochthonous vegetable crops and landraces are maintained by farmers in villages where improved cultivars do not usually perform well, such is the case in marginal environments or in 

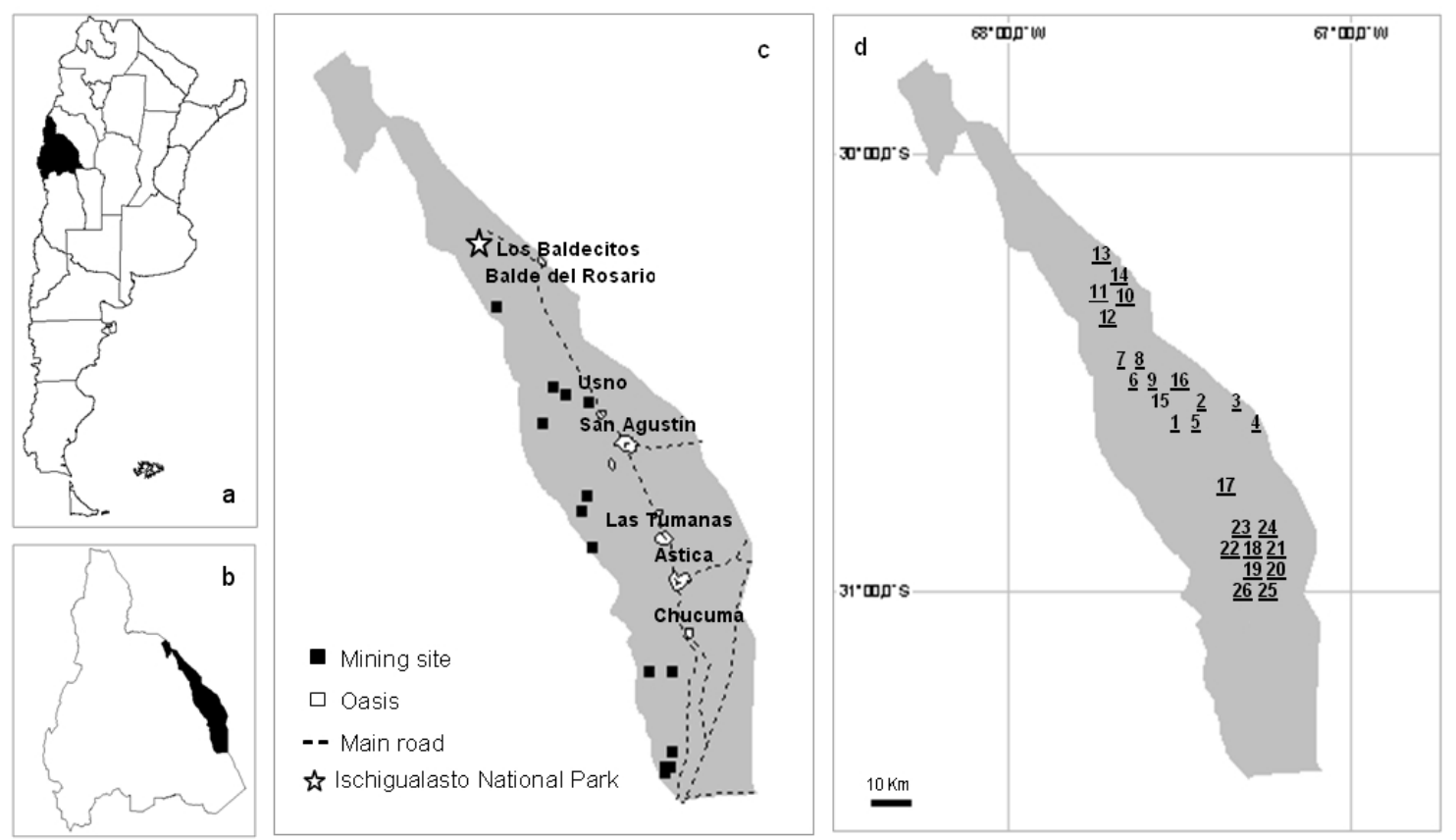

Figure 1. Location of San Juan Province in Argentina (a), location of Valle Fértil District in the San Juan Province (b), some factors in the Goodrich model for the threat of genetic erosion estimation in Valle Fértil (c) and location of collecting sample sites corresponding to table $1(d)$.

communities of certain socioeconomic conditions. Moreover, landraces are locally much appreciated by farmers for their delicious organoleptic quality. However, in the Valle Fértil region, agricultural activities are in decline due to many factors such as urbanization, land conversion to commercial agriculture with introduction of modern varieties and exotic crops. Also this decline has to do with the scarcity of water and environmental contamination by mining activities. As in other regions of Argentina, the results are reduction in the number of local farmers, loss of seed-saving and vegetative propagation skills, and farmland abandonment. (Altieri, 2003; Pengue, 2005; Asamblea de vecinos autoconvocados de Esquel, 2008).

In 1983, Argentina defined the national priorities for crops during the 'Reunión sobre Recursos Fitogenéticos de Interés Agrícola en el Cono Sur' celebrated in Brazil. These priorities were based on prevalent genetic diversity, the degree of genetic erosion, the existing collections and social and economic interest in crops. In Argentina, the National Institute of Agricultural Technology (Instituto Nacional de Tecnología Agropecuaria, INTA) established, in 1988, a National System of Genetic Resources (Sistema Nacional de Recursos Genéticos, SNRG) organized as a network of germplasm banks. The Experimental Station La Consulta INTA, Mendoza, is committed to maintain vegetable crop
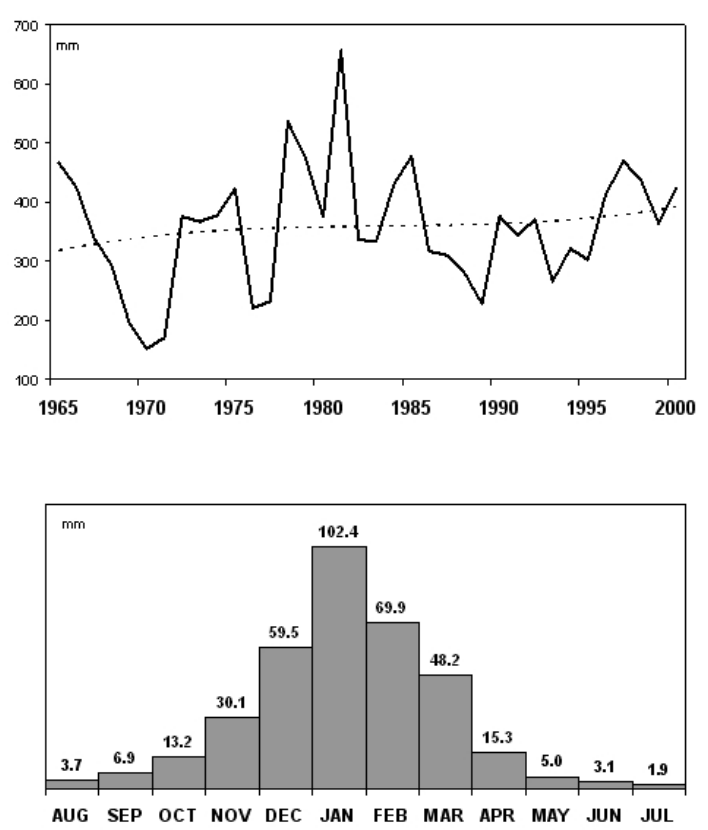

Figure 2. Annual (top) and monthly (bottom) mean rainfall from 1965 to 2000 in the Valle Fértil District, San Juan, Argentina.

germplasm useful in breeding programs. The Faculty Agronomy of the National University of Cuyo (FCA-UNCuyo) and INTA are currently developing a program to recover and evaluate traditional 
horticultural varieties cultivated in the mountainous areas close to Los Andes in Argentina. The objectives of this work were to retrieve and safeguard a representative collection of traditional vegetable crop genetic resources present in the Valle Fértil District, and to document the farmers' crop experiences and uses.

\section{MATERIALS AND METHODS}

In March 2005, a survey expedition was carried out in Valle Fértil District, San Juan, Argentina. This expedition initiated a recovery plan of landraces in the Valleys in Los Andes region, in the framework of a collaborative project implemented by INTA and the FCA-UNCuyo, and financed by ANPCYT, the National Agency for the Promotion of Science and Technology in Argentina. The expedition was focused on the recovery of landraces populations, based on socioeconomic and agroclimatic data. Information about the primitive cultivars availability was gathered by a local agricultural officer of INTA Prohuerta Program.

The information was collected and carried out along main and local secondary roads visiting San Agustín and Barriales in the East; Usno, Baldes del Rosario and Baldecitos in the North; and Las Tumanas, Astica, Chucuma, Baldes del Sur and Bajos de Astica in the Southern region of the district. Farmers were visited in the fields and at their homes, and were informed about the purpose of our research. Seeds and fruits of traditional landraces were sampled from farmers' storages and fields, and they were representative of the population. Each sample was identified with collecting date, donor name, landrace type, common name and a description of the crop environment following international descriptors (IPGRI, www.ipgri.cgiar. org). At each collecting site, the latitude, longitude and altitude were obtained with a hand-held global positioning system, GPS (Figure 1).

The conversations with the farmers were open and informal but with some pre-defined questions, using a semi-structured interview method (Jarvis et al., 1998). The main information gathered included names of donors, description of the landraces, agricultural practices and environmental adaptation, seed-management, uses and reasons for growing these landraces. The farmers were asked about the history of a landrace in the village, its differences from other local cultivars grown in surrounding villages or other nearby places. They were also interviewed about differences between present-day landraces and the landraces they had known since their youth. Farmers were also encouraged to show the crops in the fields, whenever possible, depending on the crop development stage and availability of plants. All this information was recorded into a specifically designed form, and written complementary information was recorded after the interview.

A basic aspect of the ecological study of communities is the relative importance in terms of the number of individuals of each 'species' in the community (Shanon \& Weaver, 1949). The diversity of the collected landraces was analyzed through the Shanon and Weaver index (1949) as: $H^{\prime}=-\Sigma p_{i} \cdot \log p_{i}$, where $p_{i}$ is the frequency of species $i$. When the number of species in the sample is greater, the index value and the diversity increases. The homogeneity of the sample was examined through the Margalef index $(H=L n S / L n N)$, were $S$ and $N$ are the number of species and the number of samples collected per species, respectively. This index ranges from 0 to 1 , and it takes the highest range when all the individual samples belong to different species (Fernandez Alés \& Leiva Morales, 2003). The Simpson index $\left(D=\Sigma p_{i}^{2}\right)$, that ranges from 0 to 1 , was used to estimate the pattern of dominance in the sample. The square term in the formula gives more weight to the more abundant species, and therefore a high value of dominance is shown (Fernandez Alés \& Leiva Morales, 2003).

To estimate the threat of genetic erosion in the collecting area, the Goodrich model was considered (Goodrich, 1987). This model takes a quantitative approach and is based on scoring a variety of biological, environmental and socioeconomic factors. The factors included in the model were taxa distribution, drought, flooding, accidental fires. Area under the crop availability and use of modern cultivars is also taken into account. Other factors that are included in the model were: performance of agricultural services, mechanization, herbicide and fertilizer use. Farming population, average proximity to borehole or other all-year around water supply, distance to major population centers, distance to major road and distance to development projects (tourism complexes, mining sites) are also important factors which are worth being considered. The sum of factors generates a score that estimates the threat of genetic erosion.

\section{RESULTS AND DISCUSSION}

Fifty families, located between 30 $13.3^{\prime}$ $31^{\circ} 04.2^{\prime} \mathrm{S}, 67^{\circ} 14.5^{\prime}-67^{\circ} 41.8^{\prime} \mathrm{W}$, and $636-1249$ m.a.s.l., were interviewed during this collecting expedition. Twenty-six of them donated a total of 49 samples of landraces (Table 1), 38 belonging 
Table 1. Collection sites (see figure 1), latitude, longitude, altitude and number of landraces sampled in the Valle Fértil District, San Juan, Argentina.

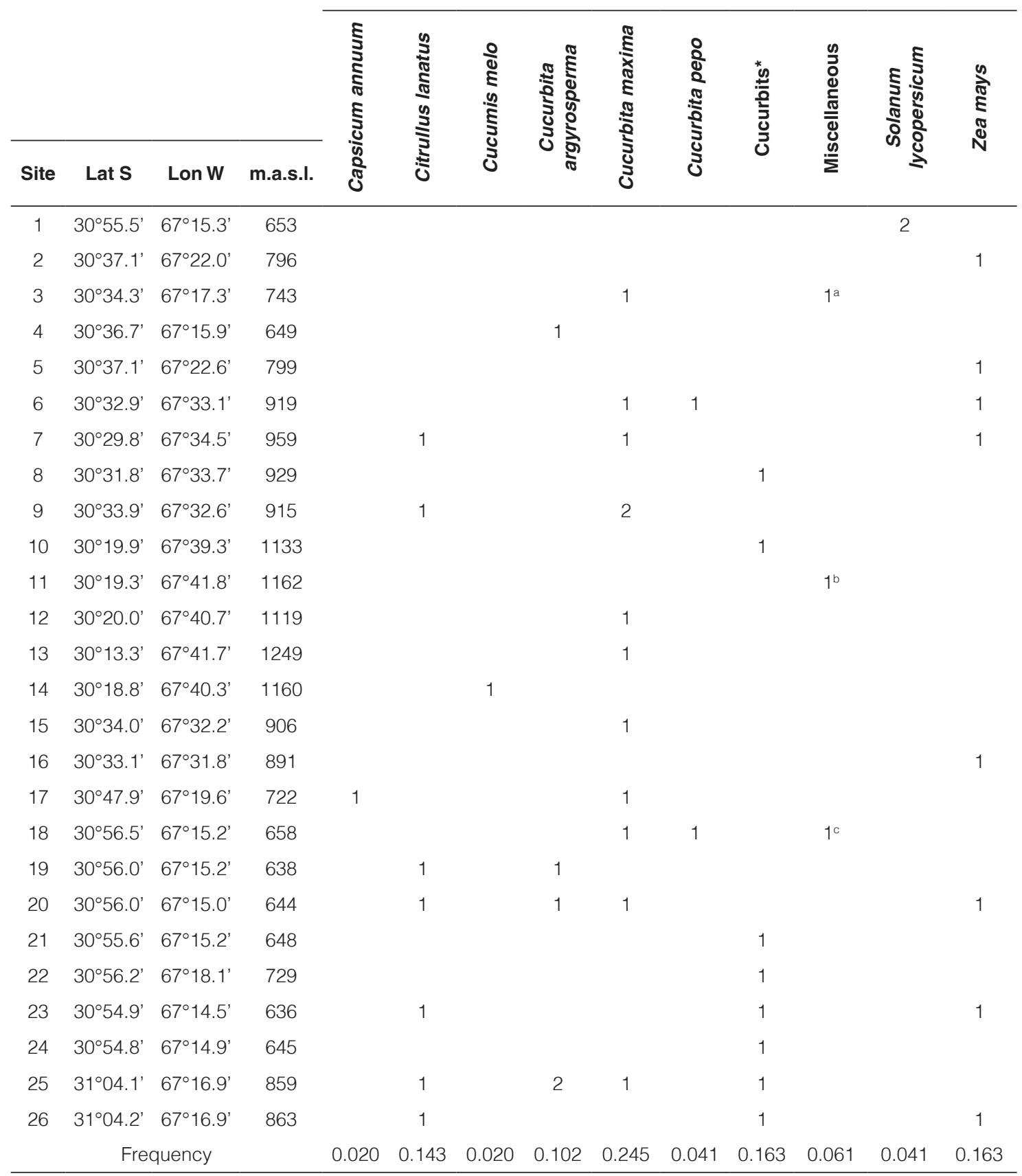

*: two or more different cucurbits seeds mixed

a: Cucurbita sp., Sorghum sp. and Zea mays

b: Cucurbita sp. and Phaseolus sp.

c: Citrullus lanatus and Cucurbita sp. 
to eight species (Cucurbita maxima Duchesne, Zea mays L., Citrullus lanatus (Thunb.) Matsum. \& Nakai, Cucurbita argyrosperma C. Huber, Solanum lycopersicum L., Cucurbita pepo L., Cucumis melo L. and Capsicum annuum L.). The rest of the samples consist of cucurbits and admixtures of different vegetable crop seeds. According to the national priorities for crop conservation, Zea mays has a high priority, and Capsicum annuum, Cucurbita maxima and Cucurbita pepo have intermediate priority (Esquinas Alcázar, 1983).

Farmers gave descriptions of landrace traits that they considered important. These included mostly botanical traits, possible uses, quality aspects, specific adaptation, and other information such as local names. Other important aspects given by farmers were advantages and disadvantages of specific growing conditions of their varieties, and also their reasons for the preference of a particular landrace growth. Food quality, alimentary traditions and adaptation to poor growing conditions of their landraces were the most commonly given reasons.

The collection was composed of 49 heterogeneously represented landraces. Comparing the diversity distribution with the vegetation features in the lower basin of the Paraná River, Argentina (Quintana et al., 2005), in the Valle Fértil Department, we found a relative low landraces diversity $\left(H^{\prime}=0.885\right)$ with a low homogeneity $(H=0.592)$ and a significant dominance pattern $(D=0.152)$. The frequency in landraces shows a geometric distribution (Figure 3), typical in communities in Valle Fértil with low number of species and a pattern of dominance. It is important to point out that the relative abundance of each landrace is proportional to the resource used or the ecologic space occupied (Fernandez Alés \& Leiva Morales, 2003). Through the sample process, it could be perceived that common species (i.e. cucurbits and corn) can be sampled in almost all the collection sites, such as in open fields, where minimum care of the crop is required, and where rare species (i.e. tomato and pepper) are characteristic of specific environments, such as family backyards, where these species are grown. A similar pattern of vegetable crop landraces was found in Ecuador (Nuez et al., 1993) across the Callejón Interandino Valleys.

The diversity of landraces is mainly affected by social traditions, distance from urban areas, crop practices and environmental factors. Dahl \& Nab-

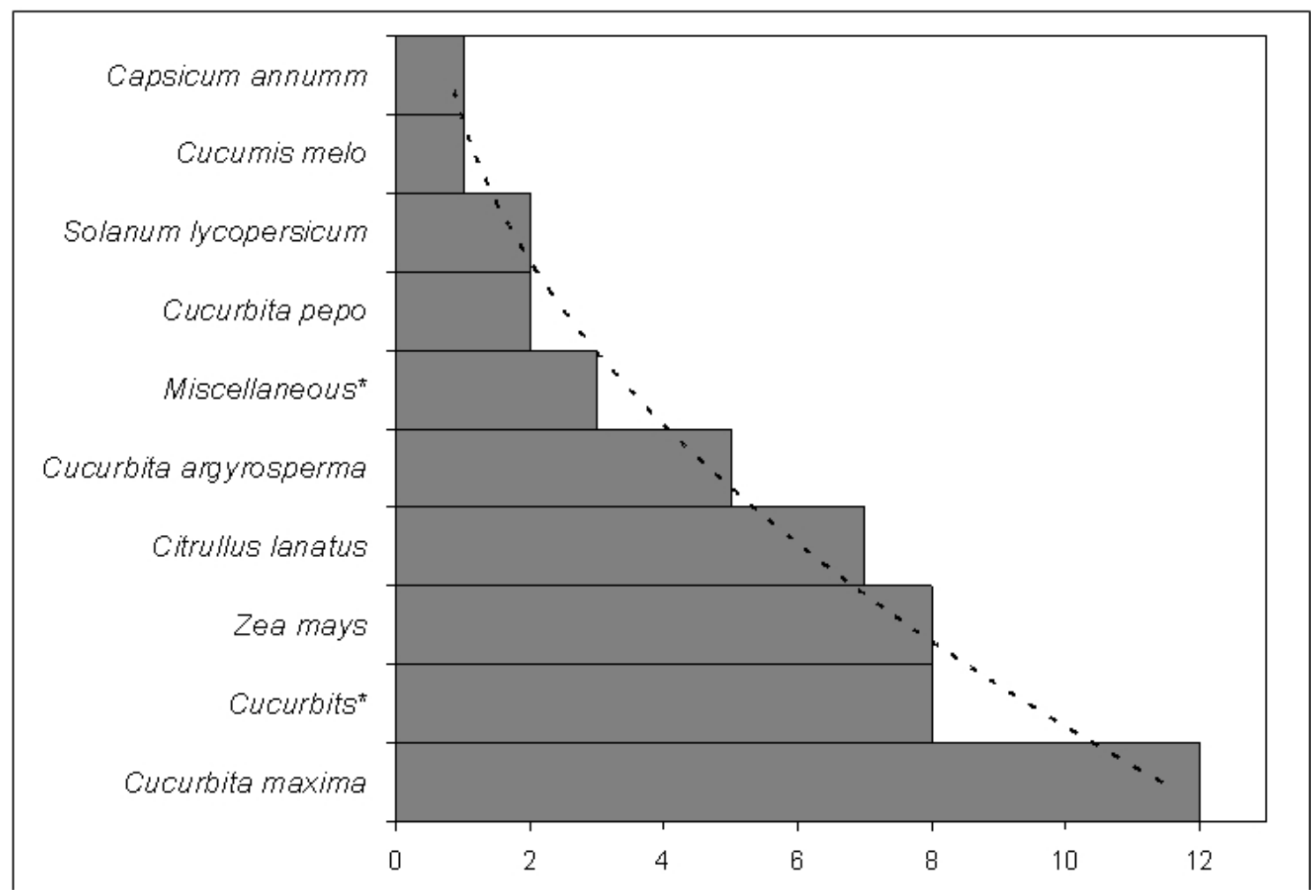

Figure 3. Number of samples per species collected in Valle Fértil District, San Juan, Argentina (*: see table 1). 
ha (1992) discuss that the introduction of modern varieties and exotic crops, the loss of seed-saving practices and the acculturation or death of traditional caretakers are considered among the major threats in crops. Moreover, the change in economic base, the destruction of habitat and farmland, environmental contamination and the reduction in the number of farmers, also constitute major threats endangering the genetic diversity of cultivated plants. Following the Goodrich model, the highest value possible of the sum of factor scores was 145 , which indicates the highest threat. The sum of scores for the fourteen considered factors was 80 , meaning that this area has a threat of genetic erosion of $55.2 \%$ (Table 2).

During our survey, a concern about a considerable decrease in agricultural activities in Valle Fértil was expressed, and it was agreed that this situation has become more evident in the last 20 years. An important social factor is the high unemploy-

Table 2. Factors and scores in the Goodrich model for the threat of genetic erosion estimation in the Valle Fértil District, San Juan, Argentina.

\begin{tabular}{|c|c|c|}
\hline Factor & States (value) & Score \\
\hline Taxa distribution & $\begin{array}{l}\text { Rare }(10) \\
\text { Locally common }(5) \\
\text { Abundant }(0)\end{array}$ & 10 \\
\hline Drought & $\begin{array}{l}\text { Two or more consecutive years }(10) \\
\text { One or more times every ten years }(5) \\
\text { Less than once every ten years }(0)\end{array}$ & 10 \\
\hline Flooding & $\begin{array}{l}\text { Area with flood prone (10) } \\
\text { Area without flood prone }(0)\end{array}$ & 0 \\
\hline Accidental fires & $\begin{array}{l}\text { Area with fire prone }(10) \\
\text { Area without fire prone }(0)\end{array}$ & 0 \\
\hline Area under crop & $\begin{array}{l}\text { Declining rapidly (10) } \\
\text { Increasing or static (0) }\end{array}$ & 10 \\
\hline Modern cultivars & $\begin{array}{l}\text { Available and used by }>70 \% \text { of farmers (15) } \\
\text { Available and used by } 50-70 \% \text { of farmers (10) } \\
\text { Available and used by }<50 \% \text { of farmers (5) } \\
\text { Not yet available, but introduction planned (2) } \\
\text { Not available (0) }\end{array}$ & 5 \\
\hline Performance of agricultural services & $\begin{array}{l}\text { Very strong and biased towards modern varieties (10) } \\
\text { No agricultural services }(0)\end{array}$ & 0 \\
\hline Mechanization & $\begin{array}{l}\text { Tractors used by }>30 \% \text { of farmers (10) } \\
\text { Animal traction used by }>50 \% \text { of farmers }(5) \\
\text { Manual labor used by }>50 \% \text { of farmers }(0)\end{array}$ & 5 \\
\hline Herbicide and fertilizer use & $\begin{array}{l}>50 \% \text { of farmers }(10) \\
25 \% \text { of farmers }(5) \\
\text { None }(0)\end{array}$ & 5 \\
\hline Farming population & $\begin{array}{l}\text { Declining rapidly (10) } \\
\text { Increasing or static (0) }\end{array}$ & 10 \\
\hline Proximity to water supply & $\begin{array}{l}<10 \mathrm{~km}(10) \\
10-20 \mathrm{~km}(5) \\
>20 \mathrm{~km}(0)\end{array}$ & 10 \\
\hline Distance to major population centre & $\begin{array}{l}<20 \mathrm{~km}(10) \\
20-50 \mathrm{~km} \mathrm{(5)} \\
>50 \mathrm{~km} \mathrm{(0)}\end{array}$ & 5 \\
\hline Distance to major road & $\begin{array}{l}<10 \mathrm{~km}(10) \\
10-30 \mathrm{~km}(5) \\
>30 \mathrm{~km}(0)\end{array}$ & 5 \\
\hline Distance to development projects & $\begin{array}{l}<20 \mathrm{~km}(10) \\
20-50 \mathrm{~km} \mathrm{(5)} \\
>50 \mathrm{~km} \mathrm{(0)}\end{array}$ & 5 \\
\hline Sum & Highest possible $=145$ & 80 \\
\hline
\end{tabular}


ment, which forces many of the inhabitants to migrate to the neighbouring cities to look for a job or further education. Thus, the area is losing its agrobiodiversity and agricultural traditions, along with its consequent social importance in planning and integration of local and agricultural development.

Local agriculture is basically a family economic activity, where soil and seed management are minimal or absent, they are also affected by the water shortage. Many farmers have lost their seeds because of drought during the summer. Others obtain water from cisterns made by individual families, reaching in some cases 30 meters deep, or from pools filled with pumps which depend on the availability of electric power. Temperature and rainfall have been described as the principal determining factors controlling taxa distribution and the development of plant communities (Ehrmann \& Maxted, 1989). Many others ecological factors have also been considered to influence the breeding tendency of many crops (Stebbins, 1952; Agong \& Ayiecho, 1991), including soil conditions, associated crops or weeds, and the presence of certain pests and diseases (Christinck et al., 1998).

The tilling with animal traction is being used by all farmers. There was an exception of one farmer who declared that he sometimes uses a tractor provided by the local government. In field-yards, called 'potreros' by local farmers, addition of manure is a common practice instead of the use chemical products. These and other practices become the selecting pressure source in the local environment, and produce associations between crops, weeds, pests and diseases. Landraces are sometimes the best choice by farmers due to quality aspects and where growing conditions are harsher. After all, the preference depended on the taste of the people, so they use vegetable landraces for their delicious organoleptic quality.

Seeds are stored in order to be protected from sun light in sacks or in glass or plastic containers, sometimes with wood-ash to prevent insect attack. So farmers acquired seeds from local markets and maintained them by continual multiplication. Since few seed markets are available for farmers, landraces are usually grown alongside other modern varieties. However, improved cultivars have not always proved to be superior when cultivated in marginal environments or under specific socio-economic conditions (Weltzien \& Fischbeck, 1990; Ceccarelli et al., 1992). In the course of our interviews, many farmers expressed their wish to have access to other sources of information and to obtain landrace seeds from other places, or other varieties, for their own crop improvement activities.
Landraces are used for food -occasionally farmers sell or barter the surplus-, and as feed for cows, goats, pigs, rabbits and fowl (chickens, geese). Families are quite resourceful to produce the seasonal products. Women are usually involved in activities such as, seed selection and storage, preparation of food and medicines, and feeding animals. Traditional food preparation depends on the vegetable products available in the different seasons. During the summer, tomato and pepper are consumed in salads and as species, melon and watermelon are consumed like fresh fruit, and squash, pumpkin and corn are used to prepare 'locro' (a local dish) and other vegetables are used for traditional dishes. Seasonal surplus is stocked up every season by housewives often as canned or dried fruits to make use of them later, during the year. For storage purposes, different strategies are used. For example, sauces are prepared with tomato and pepper or the fruits are dried under direct sunlight, ears of corn are dried away from the sun, and grains are milled or processed to obtain corn meal and starch. Starch is used for the preparation of cookies and cakes. Slices of squash and pumpkin are dried away from the sunlight, and rehydrated in water or milk before being used. Different jams are prepared with tomato, squash, pumpkin, melon and watermelon.

After the survey expedition to Valle Fértil, and taking into account the reality of local farmers and the threat of genetic erosion, we can conclude that this area is under considerable risk of genetic erosion. In order to prevent seed loss and genetic erosion, it is necessary to link in situ and ex situ conservation practices. The maintenance of vegetable crop diversity could help both farmers with their local crop-improvement efforts and the formal breeding sector. Documenting names of people and communities, who creatively contributed to the development of a specific variety and seed stocks, would facilitate the benefit-sharing of crop developments in the context of farmers' rights and intellectual property right issues (Esquinas Alcázar, 2004). Thus, a new interest could arise for using traditional landraces as such, or in breeding programs.

Authorities of the School of Agronomy of San Agustín del Valle Fértil, farmers and families were consulted about previous survey expeditions, and the conclusion was that the present research was the first one carried out as regards the safeguard of vegetable crop genetic resources. Collected landrace samples are now preserved in the Vegetable Crop Germplasm Bank of the INTA La Consulta, Mendoza, as accessions for further classification and maintenance. Field studies are currently under way to characterize these accessions of tomato, 
pepper and squash for basic and applied purposes. Future research will be focused on the distribution of DNA-marker variability to substantiate this characterization at the molecular level and to understand patterns of diversity for conservation.

\section{ACKNOWLEDGEMENTS}

We have to thank the National Agency for the Promotion of Science and Technology (ANPCyT) for the financial support on this project (FONCyTPICTO 08-12903), the Experimental Station of the National Institute of Agricultural Technology (INTA) La Consulta, and the Faculty of Agronomy, National University of Cuyo, Argentina. The commitment and contributions of the farmers and families we visited went far beyond our expectations and made this work possible. We also have to thank local agents from Prohuerta-INTA and authorities of The Superior School of Agronomy of San Agustín del Valle Fértil for valuable information and contact with local farmers.

\section{REFERENCES}

Agong, S.G.and P.O. Ayiecho, 1991. The rate of outcrossing in grain amaranths. Plant Breeding 107:156-160.

Altieri, M., 2003. Una respuesta agroecológica al problema del monocultivo en la Argentina. Available from http://www.agroeco.org/fatalharvest (accessed August 2007)

Asamblea de vecinos autoconvocados de Esquel, 2008. Autoconvocados por el no a la minería en Argentina. Available from http://www.noalamina.org (accessed March 2008).

Brown, A.H.D., 2000. The genetic structure of crop landraces and challenge to conserve them in situ on farms. In: Brush S.B. (ed). Genes in the field, on-farm conservation of crop diversity. IPGRI, Lewis publishers, Ottawa, Canada, pp. 29-48.

Ceccarelli, S.; J. Valkoun, W. Erskine, S. Weigand, R. Miller and J.A.G. van Leur, 1992. Plant genetic resources and plant improvement as tools to develop sustainable agriculture. Experimental Agriculture 28:89-98.

Christinck, A.; K.G. Kshirsagar, K. vom Brocke, E. Weltzien and P. Bramel-Cox, 1998. Report to NBPGR: Collection of Pearl Millet Landraces in Rajasthan. ICRISAT/ NBPGR/GTZ/University of Hohenheim collaborative project: Enhancing quality, diversity, and productivity of pearl millet genetic resources in Rajasthan, India.

Clausen, A.M.; M.E. Ferrer, S. Gómez and J. Tillería, 1995. Argentina: Informe Nacional para la Conferencia Técnica Internacional de la FAO sobre los Recursos Fito- geneticos (Leipzig, 1996) Available at: http://www.fao. org/ag/AGP/agps/Pgrfa/pdf/argentin.pdf. (accessed March 2008).

Dahl, K. and G.P. Nabha, 1992. Conservation of Plant Genetic Resources. Grassroots efforts in North America. ACTS Press, Nairobi, Kenya.

Ehrman, T. and N. Maxted, 1989. Ecogeographical survey and collection of Syrian Viciae and Cicereae (Leguminosae). FAO/IBPGR 77:1-8.

Ente Autárquico Ischigualasto, 2008. Valle de la Luna, Gobierno de San Juan, Argentina. Available from http://www.ischigualasto.org (accessed March 2008).

Esquinas Alcázar, J.T., 1983. Los recursos fitogenéticos de Argentina. Informe para la Reunión Regional sobre Recursos Fitogenéticos de Interés Agrícola en el Cono Sur. Brasilia, Brazil.

Esquinas Alcázar, J., 2004. International treaty on plant genetic resources for food and agriculture. Plant Genetic Resources Newsletter 139:1-6.

Fernandez Alés, R. and M.J. Leiva Morales, 2003. Ecología para la agricultura. Mundi-Prensa, Barcelona, España. 223 pp.

Frankel, O.H., 1993. Natural variation and its conservation. In: Muhamed A., R. Anksel and R.C. von Borstel (eds) Genetic diversity in plants. Plenum Press New York (USA) and London (UK), pp. 21-49.

Goodrich, W.J., 1987. Monitoring genetic erosion: detection and assessment. Unpublished consultancy document report. AGPG: IBPGR/86/99. IBPGR, Rome, Italy.

Harlan, J.R., 1992. Crops and Man. American Society of Agronomy, Inc. Crop Science Society of America, Inc. Madison, Wisconsin, USA.

INIAP (Instituto Nacional Autónomo de Investigaciones Agropecuarias, Ecuador), 1984. Colección de varios cultivos andinos en Ecuador. Informe final del proyecto INIAP-IBPGR.

Jarvis, D; T. Hodgking, P. Eyzaguirre, C. Ayad, S. Bhuwon and Guarino L. 1998. Farmer selection, natural selection and crop genetic diversity. En: Strengthening the scientific basis of in situ conservation of agricultural biodiversity on farm. IPGRI, Roma, Italia.

Lizana, C.A.; E.J. Márquez, M.L. Martínez, I. Mallamachi, A.B. Naveda, V.C. Oviedo, J.H. Maráz, R.A. Velázquez, N.G. Salinas, M. Martinelli, E.D. Graffigna, J.S. Mareca and N.V. Herrera, 2002. Atlas socioeconómico provincia de San Juan. Centro de fotometría, cartografía y catastro. Facultad de Ingeniería, Universidad Nacional de San Juan. Multimedia.

Nuez, F., R. Morales, J.J. Ruiz, P. Fernández de Córdova, E. Valdivieso and F.I. González, 1993. Recolección de especies hortícolas en Ecuador. Plant Genetic Resources Newsletter 96:29-33.

Pengue, W.A., 2005. Disyuntivas de la producción agro- 
pecuaria. Agricultura industrial y familiar en el Mercosur. El pez grande se come al chico... ¿siempre? In: Capital Intelectual S. A. Buenos Aires, Argentina (ed) Le Monde Diplomatique vol 4(71), pp7-9.

Popenoe, H.; S.R. King, J. León and L.S. Kalinowski, 1990. Lost Crops of the Incas. National Academy Press, Washington.

Quintana, R.D., N. Madanes, A.I. Malvárez, F.A. Kalesnik and M. Cagnoni. 2005. Análisis de la vegetación en tres tipos de hábitat de Carpinchos en la baja cuenca del Río Paraná, Argentina. INSUGEO, Temas de la Bio- diversidad del Litoral fluvial argentino II, Miscelánea 14:183-200.

Shanon, C.E. and W. Weaver, 1949. The mathematical theory of communication. University of Illinois Press, Urbana, Illinois, USA. 144 p.

Stebbins, G.L., 1952. Aridity as a stimulus to plant evolution. American Naturalist 86:33-44.

Weltzien, E. and G. Fischbeck, 1990. Performance and variability of local barley landraces in near-eastern environments. Plant Breeding 104:58-67. 